УДК 339.9

JEL Classification: O10; D83

МАШКІНА А. C. 1

\title{
АНАЛІЗ ВЗАЕМОДІЇ ГОЛОВНИХ ДЕТЕРМІНАНТІВ ФУНКЦІОНУВАННЯ ЕКОНОМІКИ ЗНАНЬ
}

DOI: $10.32620 /$ cher.2019.4.04

Постановка проблеми. Сучасні тенденції побудови відносин між країнами, показують, що наразі панують країни - інтелектуали. Світове лідерство вони зайняли завдяки акумулюванню знань та здібностей населення та направлення їх на досягнення суспільного прогресу i добробуту. Тож, 3 огляду на досвід цих країн, перед Україною постає багато викликів на шляху переродження. Метою cmaтmi $\epsilon$ розгляд та аналіз взаємодії головних детермінантів функціонування економіки знань. Об'єктом дослідження виступає людина - носій знань; освіта - інструмент: засвоєння, виробки нових та поширення цих знань; інновації - складова досягнення прогресу, покращення рівня умов життя населення тим самим збільшення конкурентоздатності національної економіки. За основу методологічних спостережень були взяті та проаналізовані звіти міжнародних організацій та їх рекомендації щодо змістовних принципів переходу до нової економіки. Гіпотезою дослідження $\epsilon$ думка про те, що вклад держави в всебічний розвиток людини та підтримку на протязі життя приносить великі дивіденди національному господарству. Виклад основного матеріалу. XXI століття проходить під гаслом - «людина-рушій». Виходячи 3 цього гасла, бачимо що багато країн сфокусувалися на людині, як на головному «двигуні» всіх процесів діяльності держави як всередині так і ззовні. Отже, для того щоб людина розвивалась, а разом з нею і держава, потрібне забезпечення соціального комплексу потреб, де головним виступає - освіта. Оригінальність та практична змістовність дослідження полягає у запропонованому системному зв'язку складових економіки знань. Проведене дослідження дозволяє зробити висновки, що перед Україною постає багато невирішених соціальних та економічних задач де головне місце займає - розкриття потенціалу людини.

Ключові слова:

економіка знань, глобалізація, знання, освіта, інновації.

\section{ANALYSIS OF THE INTERACTION OF THE MAIN DETERMINANTS OF THE FUNCTIONING OF THE KNOWLEDGE ECONOMY}

Formulation of the problem. Current trends in relations between countries show that intellectual countries currently dominate. They have taken on world leadership by accumulating knowledge and abilities of the population and directing them to achieve social progress and prosperity. Therefore, given the experience of these countries, Ukraine faces many challenges in the path of rebirth. The aim of the article is the consideration and analysis of the interaction of the main determinants of the functioning of the economy. The object of research is a person - a carrier of knowledge; education is a tool: assimilation, development of new and dissemination of this knowledge; innovation is an integral part of progress, improving the living conditions of the population, thereby increasing the competitiveness of the national economy. As a basis for methodological supervisions, we have taken that analysis of international organizations and their recommendations on the transition to a new economy. The practical side of lined up relations became basis of methodological supervisions between a population and government bodies all levels. A research hypothesis is that the state's contribution to comprehensive human development and lifelong support brings great dividends to the national economy. The statement of basic materials. The 21 st century is held under the slogan "man-engine". Based on this slogan, we see that many countries have focused on people, as the main "engine" of all processes of the state's activity both inside and outside. So, in order for a person to develop, and with it the state, it is necessary to ensure a social complex of needs, where education is the main thing. The originality and practical

${ }^{1}$ Машкіна Аліна Сергіївна, здобувач третього (освітньо-наукового) рівня вищої освіти - доктора філософії $(\mathrm{PhD})$ кафедри фінансів, Національний аерокосмічний університет ім. М. Є. Жуковського «Харківський авіаційний інститут», м. Харків, Україна.

Mashkina Alina, a third-level (academic) higher education student - PhD in Finance, National Aerospace University «Kharkiv Aviation Institute», Kharkiv, Ukraine.

ORCID ID: 0000-0002-5080-1063

e-mail: a.mashkina@khai.edu 
significance of the research is the proposed systemic linkage of the components of the knowledge economy. The conducted research leads to the conclusion that there are many unresolved social and economic problems where Ukraine will occupy the main place - unlocking human potential.

Key words:

knowledge economy, globalization, knowledge, education, innovation.

\section{АНАЛИЗ ВЗАИМОДЕЙСТВИЯ ГЛАВНОЙ ДЕТЕРМИНАНТОЙ ФУНКЦИОНИРОВАНИЯ ЭКОНОМИКИ ЗНАНИЙ}

Постановка проблемы. Современные тенденции построения отношений между странами, показывают, что в настоящее время господствуют страны - интеллектуалы. Мировое лидерство они заняли благодаря аккумулированию знаний и способностей населения и направления их на достижение общественного прогресса и благосостояния. Поэтому, учитывая опыт этих стран, перед Украиной стоит много вызовов на пути перерождения. Целью статьи является рассмотрение и анализ взаимодействия главных детерминант функционирования экономики. Объектом исследования выступает человек - носитель знаний; образование - инструмент: усвоение, выработки новых и распространение этих знаний; инновации - составляющая достижения прогресса, улучшение уровня условий жизни населения тем самым увеличение конкурентоспособности национальной экономики. Основой методологических наблюдений были взяты и проанализированы отчеты международных организаций и их рекомендации перехода к новой экономике. Гипотезой исследования является мысль о том, мнение о том, что вклад государства в всестороннее развитие человека и поддержку на протяжении жизни приносит большие дивиденды национальному хозяйству. Изложение основного материала. XXI век проходит под лозунгом - «человек-двигатель». Исходя из этого лозунга, видим что многие страны сфокусировались на человеке, как на главном «двигателе» всех процессов деятельности государства как внутри так и снаружи. Итак, для того чтобы человек развивался а вместе с ней и государство, требуется обеспечение социального комплекса потребностей, где главным выступает - образование. Оригинальность и практическая значимость исследования заключается в предложенной системной связи составляющих экономики знаний. Проведенное исследование позволяет сделать выводы, что перед Украиной стоит много нерешенных социальных и экономических задач, где главное место занимает - раскрытие потенциала человека.

Ключевые слова:

экономика знаний, глобализация, знания, образование, инновации.

Постановка проблеми. «Економіка знань», «інформаційне суспільство», «інтелектуальна економіка» - всі ці поняття характеризують глобалізаційні процеси переходу країн до якісно нового типу економіки. Економіка знань - економіка в якій головним рушієм розвитку виступає людина $з$ її знаннями, інтелектуальними здібностями та професійними навичками для досягнення суспільного та економічного прогресу. Людина, як одну 3 головних умов функціонування економіки знань потрібно розглядати через призму освіти, яку вона отримує та за допомогою якої розвивається на протязі життя. Освіта - засіб створення та формування: інтелектуального потенціалу населення, якісно нового порядку ціннісних та духовних орієнтирів. Головним в освіті $\epsilon$ - доступність, якість та змістовність, завдяки якої кваліфіковане населення створює та розповсюджує інноваційні технології виробництва, продукти та послуги для підвищення рівня суспільних умов життєдіяльності та економічної складової.

Аналіз останніх досліджень та публікацій. Першим хто ввів в обіг термін «економіка знань» - був австроамериканський економіст Фріц Махлуп. Надалі дослідженнями розвитку економіки знань займались такі вчені: Г. Беккер, М. Блауг, К. Гріффін, Е. Денісон, Р. Кроуфорд, Т. Стюарт, У. Хадсон, Т. Шульц. Українські вчені Ю. Бажал, В. Геєць, Б. Малицький, О. Марченко, А. Чухна у своїх працях також досліджують механізми впровадження та шляхи розвитку економіки знань.

Особливої уваги заслуговує:

1. Методологія «The Assessment Knowledge Methodology» та індекс «The Economy Knowledge Index», які розроблені спеціалістами Світового банку для оцінки рівня розвитку економіки знань та якісноструктурних змін продуктивних сил країн світу; 
2. Концептуальний індекс «EBRD Knowledge Economy Index» далі E3, розроблений спеціалістами Європейського банку реконструкції та розвитку далі ЄБРР, показники якого розраховують на основі даних 46 країн в які інвестує банк, для розвитку економіки знань.

Метою статті є висвітлення та аналізування взаємозв'язку головних детермінантів функціональності економіки знань.

Виклад основного матеріалу дослідження. Починаючи з 1965 року країни, які зрозуміли, що головним є не промисловість та виробництво а кваліфікована, обізнана людина яка стоїть за процесом виробництва, почали перехід до економік знань.

Конкурентоспроможність національних економік усе більшою мірою залежить від здатності цих економік продукувати та використовувати знання. Знання, освіта, інформація та інновації $\epsilon$ на сьогодні головними індикаторами економічного зростання в контексті становлення нових глобальних моделей розвитку та формування інноваційних стратегій розвитку національних економік [1].

3 дослідження Світового банку «Глобалізація, зростання і бідність: формування загальної світової економіки» [2] в якому описаний досвід 24 країн, які більше за всіх здійснюють перехід до знаннєвої економіки, спостерігається зв'язок між зростанням від- сотка громадян країни які здобули вищу освіту та скороченням відсотка населення які знаходились за межею бідності тим самим покращуючи показник здоров'я та підвищуючи темпи економічного росту.

Виходячи 3 глобалізаційних процесів переходу до нової економіки, можна сформувати детермінанти та взаємозв'язок між ними, за допомогою якого досягається впровадження, функціонування та розвиток економіки заснованої на знаннях (рис. 1).

Освіта - одна 3 головних умов економіки знань. За допомогою освіти людина набуває знання, досвід та вміння застосовувати набуті компетенції у професійній діяльності та повсякденному житті.

Країни, в яких зумовлений перехід до економіки знань за останні роки значно зросла тривалість навчання, а також формується тенденція - «безперервна освіта» на протязі життя.

В Україні терміни навчання за всіма рівнями освіти розроблені за міжнародними стандартами (табл. 1).

В різних наукових джерелах, присвячених економіці знань можна зустріти такі поняття: «людський потенціал», «людський ресурс», «людський капітал». Всі ці поняття відображають людину, яка в процесі освіти набула знання та яка вміло застосовує їх та розповсюджую своєю професійною діяльністю.

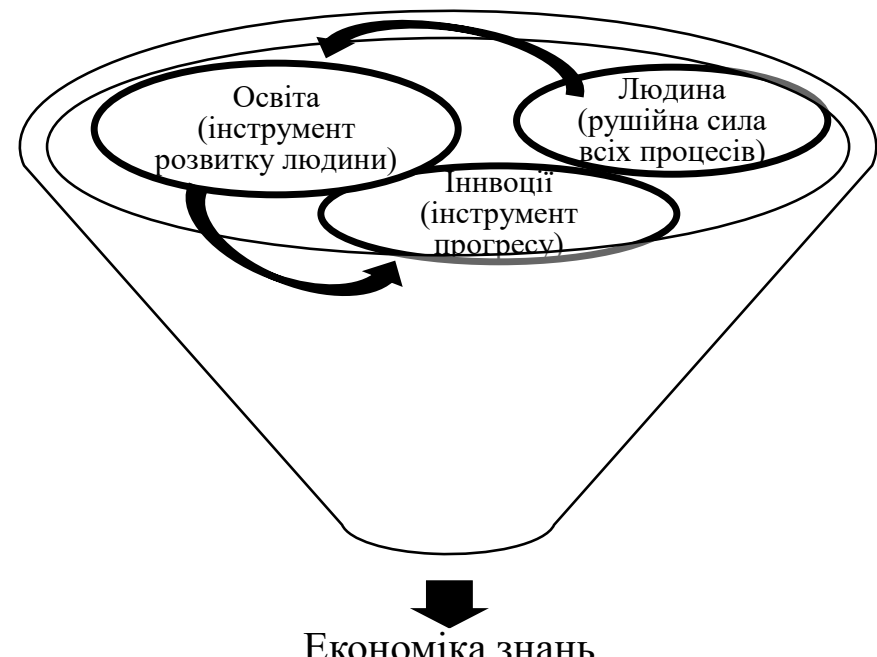

Економіка знань

Рисунок - 1 Взаємозв'язок головних детермінантів економіки знань Джерело: розроблено автором 
Співставлення освітніх рівнів за Міжнародною стандартною класифікацією освіти МСКО 2011 з національними освітніми програмами

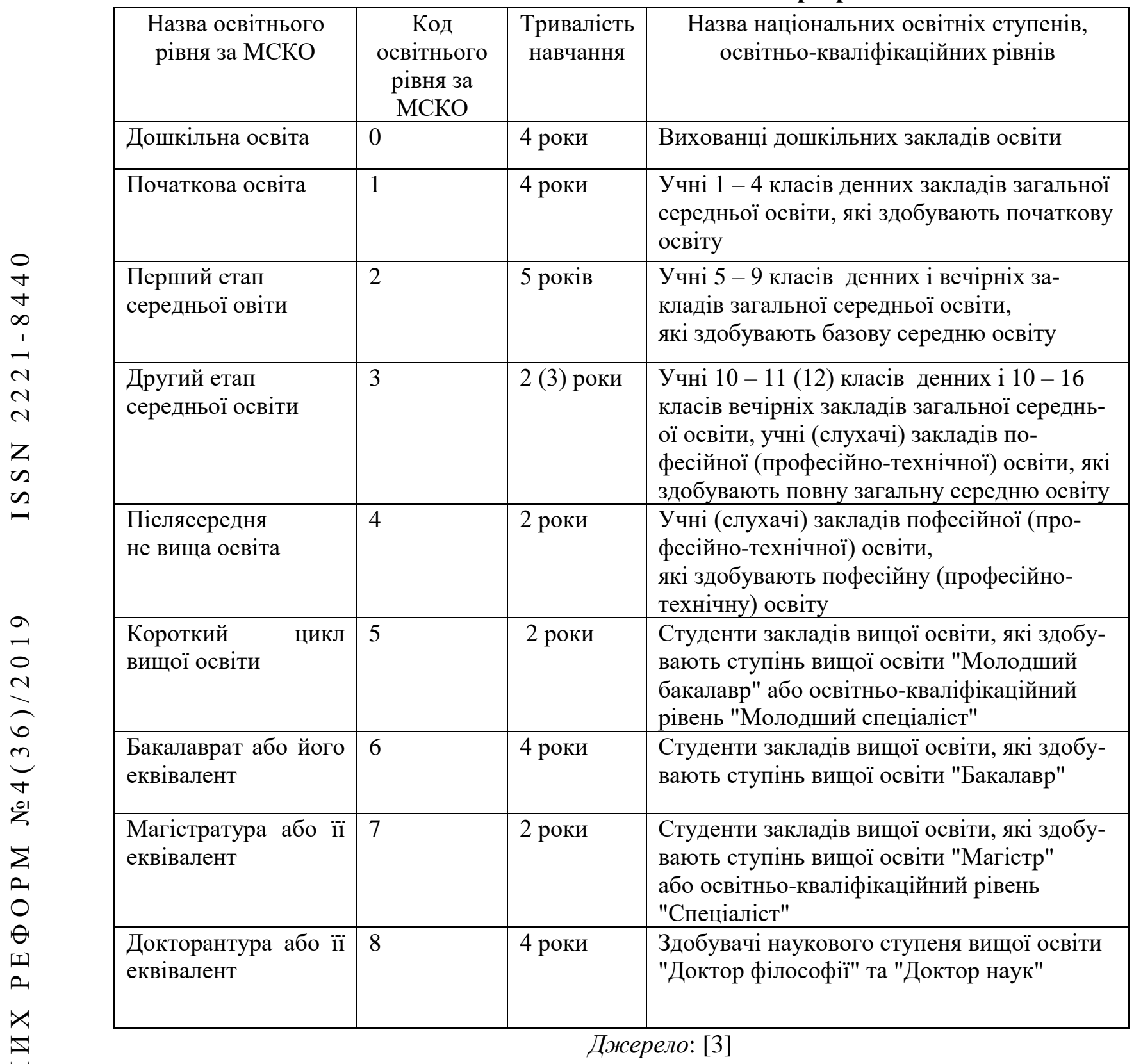

Отже, освіту, як одну з головних детермінантів функціонування економіки знань, потрібно розглядати в контексті соціальноорієнтовного інструменту держави, за допомогою якого кожний індивід набуває знання, користується та які трансформує у створення ліпших умов життя своєю професійною діяльністю (табл. 2).

Інновації - детермінанта, яка є завершальним етапом на шляху підвищення конкурентоспроможності - головної цілі економіки знань.

В контексті досягнення економічного зростання розвиток інновацій розуміється як - використання досягнень людського розуму для підвищення ефективності діяльності в тій чи іншій сфері [4].

В сьогоденних реаліях в побудові стосунків між країнами спостерігається домінування інтелектуальних країн. Яскравими прикладами таких країн є: Японія, США, Нiмеччина, Південна Корея, Сінгапур та Тайвань.

Японію можна вважати першою країну, яка досягла високого інтелектуального, інноваційно-технологічного та інформаційного розвитку завдяки вкладу в людину, як носія знань, створила всі умови для того щоб знання кожного громадянина примножувались, розвивались та працювали на суспільний до- 
бробут. Розглядаючи досвід цих країн можна зробити висновок, що вони досягли значущого розвитку в усіх сферах завдяки згуртованості та системної взаємодії ланок, таких як - «державанаука-підприємства».

Для країн, які здійснюють перехід до економіки знань дуже важливим є інноваційність продуктів, послуг, технологій, за допомогою яких можна залучити іноземні інвестиції тим самим збільшуючи конкурентні переваги.

Іноземні інвестори, перед ти як вкладати кошти користуються аналітичними звітами та статистичними даними різних провідних фірм, установ та фондів.

СБРР, запровадив індекс Е3 та детально розрахував інноваційні процеси в країнах, які $\epsilon$ партнерами банку, в березні 2019 представив аналітичний звіт, в якому сформовано стадії розвитку ЕЗ, кожна стадія має характеристику процесів та для кожної стадії виділена країна, яка більш за всіх відповідає той чи іншій стадії (табл. 3).

Стадії розвитку Економіки знань (ЕЗ)

\begin{tabular}{|c|c|c|}
\hline Стадія & Характер (ознаки) стадії & Країна \\
\hline Рання стадія розвитку Е3 & $\begin{array}{c}\text { Слабкі інституції та навички для підтримки та } \\
\text { розвитку інноваційної діяльності }\end{array}$ & Україна \\
\hline Перехідна стадія розвитку Е3 & $\begin{array}{c}\text { Покращені інституції та навички, співвідносні з } \\
\text { поліпшенням інноваційної діяльності }\end{array}$ & Північна Македонія \\
\hline Передова стадія розвитку Е3 & $\begin{array}{c}\text { Сильні інституції та навички розвитку іннова- } \\
\text { ційної діяльності }\end{array}$ & $\begin{array}{c}\text { Угорщина, } \\
\text { Словаччина }\end{array}$ \\
\hline
\end{tabular}

Джерело: розроблено автором на основі [5]

Т а б ли ц я 2

Т а б ли ц я 3

Освіта - соціально-орієнтовний інструмент держави

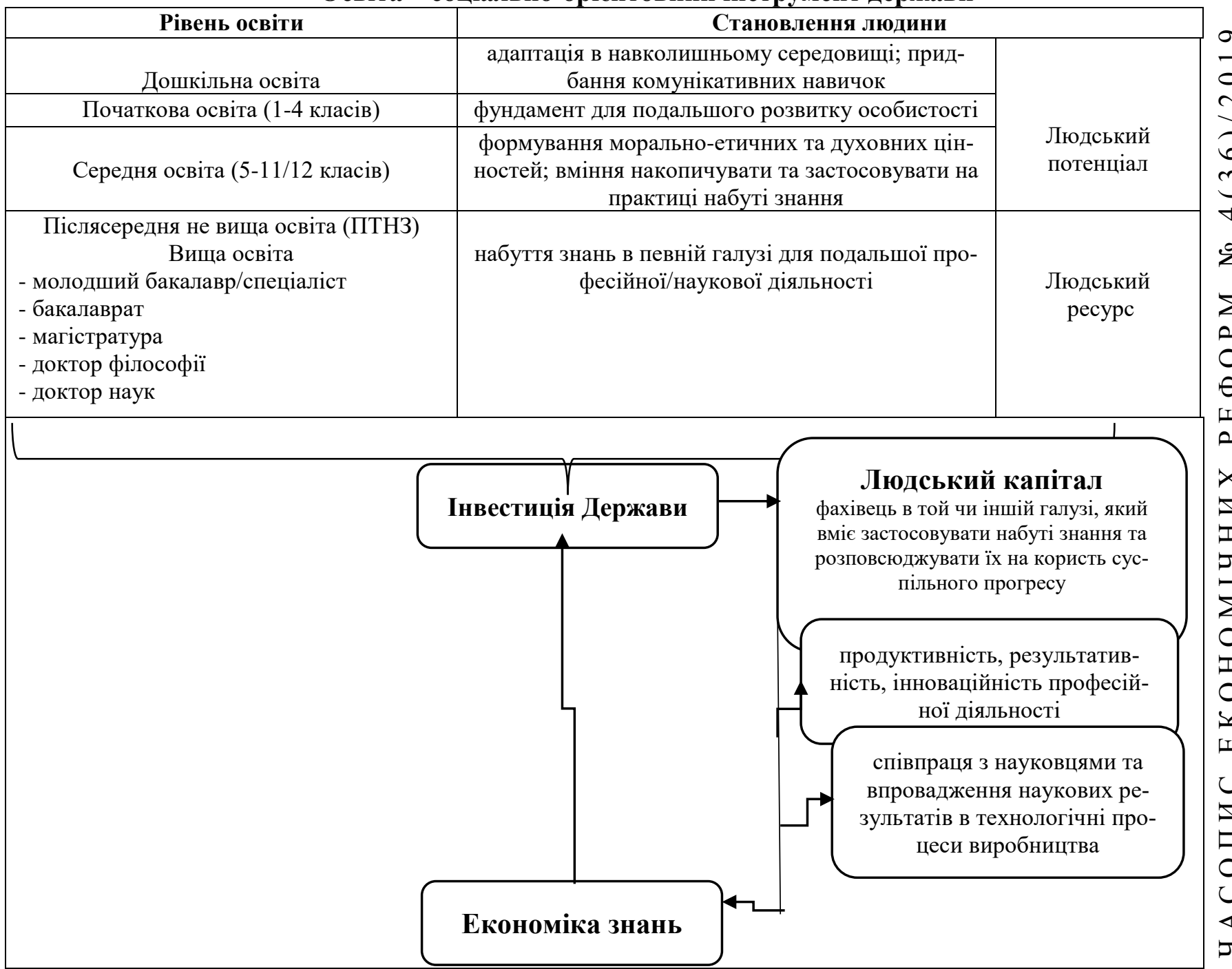


Висновки та перспективи подальших досліджень. Висвітливши головні складові на яких базується економіка знань, взаємодію та зв'язок між ними, міжнародний досвід країн, які вже повністю чи в більшій мірі керуються принципами нової економіки, поставили перед Україною вирішення таких нагальних питань: 1) забезпечення і виконання всіх соціальних гарантій, та насамперед гарантування здобуття освіти, як головної складової розвитку всієї країни; 2) висвітлення реальних розрахунків стану економіки та на основі цього чітко сформовані пріоритетні галузі народного господарства, які в подальшому займуть конкурентні позиції на міжнародному полі; 3) виходячи 3 досвіду країн-лідерів, Україні потрібно вистроїти та налагодити безперебійну систему взаємодії та співпраці між: державним апаратом, який підтримує та забезпечує розвиток інтелектуальноінноваційної діяльності за допомогою науковців, які в свою чергу співпрацюють 3 підприємства за для комерціалізації своїх інтелектуальних надбань поліпшуючи умови соціального та економічного становища країни; 4) налагоджена інфраструктура каналів передачі інформації.

Отже, подальші дослідження будуть полягати в аналізуванні політичного, законодавчого та інституційного середовища в якому $\epsilon$ багато протиріч та перешкод на шляху трансформації та переродження в нову інтелектуально-прогресивну державу.

\section{Література}

1. Дорошенко О. С. Економіка знань базис економічного зростання та економічного розвитку країн. Науковий вісник Херсонського державного університету. 2016. № 17. C. 27-31.

\section{Стаття надійшла}

до редакції : 01.12.2019 p.
2. The World Bank Group. URL : https://www.worldbank.org/ (дата звернення : 11.11.2019 p.)

3. Демографічна та соціальна статистика. Освіта. Офіційний сайт Державної служби статистики України. URL: https://ukrstat.org/uk/operativ/menu/menu_u/osv .htm (дата звернення : 10.11.2019 p.)

4. Онишко С. В., Паєнтко Т. В., Швабій К. І. Фінансове забезпечення інновачійної діяльності: навчальний посібник. Київ: КНТ, 2008. $256 \mathrm{c}$.

5. European Bank for Reconstruction and Development. EBRD Knowledge Economy Index. URL: https://www.ebrd.com/ news/publications/brochures/ebrd-knowledgeeconomy-index.html (дата звернення 11.11.2019 p.)

\section{References}

1. Doroshenko, O. (2016). The knowledge economy - the basis of economic growth and economic development of countries. Scientific Bulletin of the Kherson State University, 17, 2731.

2. The World Bank Group. Retrieved from: https://www.worldbank.org/

3. Demographic and social statistics. Education. Official web site of the State Statistics Service of Ukraine. Retrieved from: https://ukrstat.org/uk/operativ/menu/menu_u/osv .htm

4. Onyshko, S. V. \& Paientko, T. V. \& Shvabii, K. I. (2008). Financial providing of innovative activity: Train aid. Kyiv: KNT, 256.

5. European Bank for Reconstruction and Development. EBRD Knowledge Economy Index. Retrieved from: https://www.ebrd.com/news/publications/brochu res/ebrd-knowledge-economy-index.html

\footnotetext{
Стаття прийнята

до друку: 27.12.2019 р.
}

Бібліографічний опис для цитування :

Машкіна А. С. Аналіз взаємодії головних детермінантів функціонування економіки знань / А. С. Машкіна // Часопис економічних реформ. - 2019. - № 4 (36). - С. 29-34. 